\title{
Adoption of Calliandra Calothyrsus for Improved Dairy Production in Embu County, Kenya
}

\author{
Paul Tuwei* $^{*} \quad$ Ebby Chagala Odera Jonah Kiprop Josephine Wanjiku \\ Kenya Forestry Research Institute - Muguga P.O Box 20412 00200, Nairobi Kenya
}

\begin{abstract}
Small-scale dairy production plays a significant role in food production and income generation in Embu County. However, dairy animals in the county rarely meet their full potential of milk production mainly due to inadequate fodder in terms of quantity and quality. Napier grass (Pennisetum purpureum) is the main feed for the animals. However, Napier grass is low in protein and produces little biomass during the dry season. Leguminous fodder trees including Calliandra calothyrsus are evergreen even during the dry season and have foliage rich in protein which can supplement the main diet of animals. This study was undertaken in Embu County in 2015 to assess adoption of Calliandra calothyrsus as a fodder. The study was conducted through a field survey using a structured questionnaire. The study involved interviewing 184 farmers, of which 124 were agroforestry farmers producing fodder trees and 60 non-fodder tree producing farmers. The results of the survey showed that $86 \%$ of the sampled farmers had adopted growing of Calliandra tree fodder. These farmers noted that the tree had multiple benefits that included; increased and improved dairy milk production from cows and goats as indicated by about $92 \%$ of the farmers, and improved quality of manure (84\%). Age, gender, years in education and land size was the key socio-economic factors influencing adoption of Calliandra. Calliandra calothyrsus is an important fodder tree in Embu County contributing to; increased and improved milk production, providing food supplement for other livestock enterprises, conservation of soil and improved quality of manure.
\end{abstract}

Keywords: Dairy farming, Embu County, Calliandra calothrysus, Adoption, Agroforestry

DOI: $10.7176 / \mathrm{JBAH} / 9-10-02$

Publication date:May $31^{\text {st }} 2019$

\subsection{Introduction}

Kenya's economy is heavily reliant on agriculture. The sector contributes $30 \%$ of Kenya's Gross Domestic Product and accounts for $80 \%$ of the national employment (GOK, 2010). Agriculture is the primary source of livelihoods for the many small scale land holders. Any adverse effects on the agricultural sector directly compromises economic development, food security and poverty alleviation in Kenya. The major challenge for smallholder farms in Kenya is to meet the ever growing demand for agricultural products while conserving biodiversity, providing critical ecosystem services and maintaining rural livelihoods (Barrios, 2007; Harvey et al., 2008). The farming sector faces numerous challenges including declining productivity of both crops and domestic animals, overgrazing, land degradation and soil erosion, hence the need to adopt more sustainable agricultural practices. Agroforestry is a promising alternative to overcome this challenge. Agroforestry is an integrated approach which combines sustainable farming production and biodiversity conservation (Jerneck and Olsson 2013; Pretty et al., 2006). Over the years agroforestry practice has been recognised as an important tool in meeting ecological, economic and social needs of humans. The adoption of agroforestry practices including fodder shrubs is considerably more complex than traditional agriculture because it usually requires establishing a package of activities which integrates trees, crops and livestock and other components, combined with new conservation techniques such as contour hedgerows, wind breaks, alley cropping, and enriched fallows (Hyde and Köhlin, 2000).

Dairy farming for many Kenyan small scale farmers is an important venture due to its contribution to household incomes, food security and provision of manure for crops (Karanja, 2003), the potential for milk productivity has been low, for instance in Embu County milk productivity at farm level was reported to be on average about $8 \mathrm{~kg} / \mathrm{cow} /$ day (Minae and Nyamai, 1988; Murithi, 1998). This can be improved through better use of available resources and current state of technology (Mugambi, 2014). Inadequate and low-quality feed is a major cause of low dairy animal productivity. Fodder shrubs such as Calliandra calothyrsus provide valuable feed supplements to dairy animals especially during the dry season when the basal diet Napier grass is low in protein and produces less biomass (Minae and Nyamai 1988). Unlike conventional agriculture, the system is more knowledge-intensive. Calliandra calothyrsus is a leguminous tree that originates from Central America and Mexico (Gutteridge and Shelton, 1994). It is a large multi-stem shrub growing to a height of $4-6 \mathrm{~m}$ (Maundu and Tengnas, 2005). The shrub grows well on a broad range of soil types ranging from deep volcanic loams to more acidic metamorphic sandy clays. Calliandra grows at an altitude from 0-1,850 metres above sea level. The maturity period for fodder production after planting is 8-12 months (Cook et al., 2005). Calliandra fed fresh was found to have about $24 \%-28 \%$ per cent crude protein. There are numerous benefits attributed to adoption of fodder technologies among rural households in Kenya. However, few studies have been conducted to 
examine the benefits of adopting fodder agroforestry practices. The objectives of this study were to; assess the benefits of fodder technology, determine factors influencing its uptake, identify constraints and the most efficient technology dissemination pathways.

\subsection{MATERIALS AND METHODS}

\subsection{Study Site}

Embu County covers an area of 2,818 square $\mathrm{km}$ with a population density of 183 people per square $\mathrm{km}$. In addition, the county receives a bimodal rainfall pattern, with the peak rainfall occurring between March and June, and short rainfall between October and November. On average the rainfall ranges between 1,200-1,500 $\mathrm{mm}$ annually. Temperatures range from a minimum of $16^{\circ} \mathrm{C}$ to a maximum of $23^{\circ} \mathrm{C}$. The main cash crops grown were coffee and tea, while food crops were maize and beans. Dairy farming is a major activity in the county. The study was carried out in Embu County in the eastern region of Kenya formerly known as Eastern Province (Figure. 1). Dissemination of fodder technologies in the County was undertaken jointly by National Agroforestry Research Project (NAFRP), Kenya Forestry Research Institute (KEFRI) Kenya Agricultural Research Institute now Kenya Agricultural Livestock Research Organization (KALRO) and International Centre for Research in Agroforestry (ICRAF) in the early 1990's. The objective of the project was to introduce and promote a package of agroforestry fodder species namelythat included; Calliandra calothyrsus, Leucaena Species, Pennisetum purpureum, Tithonia diversifolia, Morus alba, Ficus thonningii and Grevillea robusta. The project targeted 150 farmer groups comprising 2,600 farmers. On average each farmer received 400 fodder shrub seedlings of assorted target species.



Figure 1: Study site showing sub-counties in Embu County

\subsection{Data collection and analysis}

Data was collected in 2015 from farmers who adopted the technology and non-adopters residing within the areas where Calliandra was introduced. A structured questionnaire was administered to 124 farmers planting and using fodder plants and 60 non-adopters. The data was entered and analysed using SPSS statistical software. Descriptive statistics were used to assess the benefits accruing from growing of fodder trees $\mathrm{s}$, the household and land characteristics influencing adoption. To determine the factors influencing the adoption of fodder technologies the logistic regression model was applied. 


\subsection{RESULTS}

\subsection{Socio economic and demographic characteristics}

The study findings revealed that the initial project farmers and adopters were relatively older with mean ages of 62 and 60 years respectively as compared with non-adopters who were much younger with a mean age of 58 years (Table I). Land size varied with the original farmers having the largest farm size with a mean of 2.4 acres; adopters had a mean land size of 2 acres while non-adopters had the smallest landholding with a mean of 1.2 acres.

Table I: Farmer demographic characteristics and their farm size

\begin{tabular}{llllllc}
\hline Type of farmer & Variable & N & Minimum & Maximum & Mean & $\begin{array}{c}\text { Standard } \\
\text { deviation }\end{array}$ \\
\hline Original & Age (years) & 62 & 35 & 96 & 62 & 15.0 \\
& Farm size (acres) & 62 & 0.3 & 9 & 2.4 & 1.80 \\
Adopters & Age (years) & 62 & 30 & 90 & 60 & 15.4 \\
& Farm size (acres) & 62 & 0.1 & 6 & 2.0 & 1.50 \\
Non-adopters & Age (years) & 60 & 28 & 87 & 58 & 13.6 \\
& Farm size (acres) & 60 & 0.1 & 5 & 1.2 & 0.9 \\
\hline
\end{tabular}

1 acre $=0.4$ ha

In terms of gender, male farmers dominated female counterparts in all the three categories (Table II). Among the adopters, $84.1 \%$ were male while $15.9 \%$ were female. While in the non-adopters category $88.3 \%$ were male and $11.7 \%$ were female.

Table II: Gender percentage distribution by type of farmer category

\begin{tabular}{llll}
\hline Type of farmer & Gender & Frequency & Percent \\
\hline Original & Male & 51 & 83.6 \\
& Female & 10 & 16.4 \\
\multirow{2}{*}{ Adopters } & Total & 61 & 100.0 \\
& Male & 53 & 84.1 \\
Non-Adopters & Female & 10 & 15.9 \\
& Total & 63 & 100.0 \\
& Male & 53 & 88.3 \\
& Female & 7 & 11.7 \\
\hline
\end{tabular}

Concerning farmers level of education $85.3 \%$ accessed formal education with $50.5 \%$ of them attaining primary education, $29.9 \%$ attained secondary and only $4.3 \%$ attained tertiary education. On occupation, $70 \%$ of the respondents had farming as main occupation 19.7\% engaging in business, $11 \%$ salaried employment and $2.7 \%$ work as casual labours (Table III).

Table III: Education level and main source of income of the household head

\begin{tabular}{lll}
\hline Education level & Frequency & Percentage \\
\hline None & 27 & 14.7 \\
Primary & 94 & 50.5 \\
Secondary & 55 & 29.9 \\
Tertiary College & 8 & 4.3 \\
Total & $\mathbf{1 8 4}$ & $\mathbf{1 0 0 . 0}$ \\
\hline Main source of household income & & \\
\hline Salaried employment & 20 & 11.0 \\
Farming & 182 & 70.0 \\
Casual labour & 7 & 2.7 \\
Self-employed business & 51 & 19.7 \\
Total & $\mathbf{1 8 4}$ & $\mathbf{1 0 0 . 0}$ \\
\hline
\end{tabular}

Majority of the farmers owned land privately $(79.8 \%)$, and few $(19.7 \%)$ had land that was under family or communal land tenure systems (Table IV). About $61.1 \%$ of the farmers had title deeds of their land, indicating secure land tenure, which can consequently encourage farmers to plant and adopt tree fodder technologies. Regarding land topography in the sampled farms $49.1 \%$ of farms were slightly sloppy, $25.9 \%$ very sloppy and $25 \%$ were relatively flat. 
Table IV: Land size and tenure

\begin{tabular}{lll}
\hline Land ownership & Frequency & Percentage (\%) \\
\hline Individual & 150 & 79.8 \\
Family & 37 & 19.7 \\
Total & $\mathbf{1 8 4}$ & $\mathbf{1 0 0 . 0}$ \\
\hline Title deed & & \\
\hline Yes & 113 & 61.1 \\
No & 71 & 38.9 \\
Total & 184 & 100.0 \\
\hline Land gradient & & \\
\hline Flat & 46 & 25.0 \\
Slightly sloping & 90 & 49.1 \\
Very sloppy & 48 & 25.9 \\
Total & $\mathbf{1 8 4}$ & $\mathbf{1 0 0 . 0}$ \\
\hline
\end{tabular}

\subsection{Fodder utilization and benefits}

The study showed that the number of households who had adopted the fodder technology utilised it under various livestock enterprises within the farm. Calliandra calothyrsus was the most adopted and utilised shrub in the farm with a majority of the farmers utilising it in all the livestock enterprises followed by Morus alba (Table V).

Table V: Agroforestry technologies package use across the livestock enterprises

\begin{tabular}{|c|c|c|c|c|c|c|c|}
\hline \multicolumn{8}{|c|}{ Promoted fodder technologies } \\
\hline $\begin{array}{l}\text { Livestock } \\
\text { type }\end{array}$ & $\begin{array}{l}\text { Calliandra } \\
\text { calothyrsus }\end{array}$ & $\begin{array}{l}\text { Leucaena } \\
\text { species }\end{array}$ & $\begin{array}{l}\text { Napier } \\
\text { grass }\end{array}$ & $\begin{array}{l}\text { Tithonia } \\
\text { diversifolia }\end{array}$ & $\begin{array}{l}\text { Morus } \\
\text { alba }\end{array}$ & $\begin{array}{l}\text { Ficus } \\
\text { thonnin } \\
\text { gii }\end{array}$ & $\begin{array}{l}\text { Tot } \\
\text { al }\end{array}$ \\
\hline Dairy cattle & 89 & 0 & 1 & 2 & 4 & 0 & 97 \\
\hline Goats & 56 & 2 & 0 & 1 & 3 & 1 & 63 \\
\hline Poultry & 38 & 0 & 0 & 2 & 1 & 0 & 41 \\
\hline Beef cattle & 30 & 0 & 0 & 1 & 0 & 0 & 32 \\
\hline Rabbits & 20 & 0 & 0 & 0 & 1 & 0 & 21 \\
\hline Sheep & 18 & 0 & 0 & 1 & 1 & 0 & 20 \\
\hline Bees & 7 & 0 & 0 & 0 & 0 & 0 & 7 \\
\hline Fish & 3 & 0 & 0 & 0 & 0 & 0 & 3 \\
\hline Pigs & 2 & 0 & 0 & 0 & 0 & 0 & 2 \\
\hline
\end{tabular}

Fodder trees have multiple benefits to the farming system. The benefits included; increased and improved milk production from dairy cows and goats as noted by $92 \%$ of the farmers, improved quality of manure (84\%) and increased egg production $(84.6 \%)$. Other benefits that accrued to the household included improved quantity and quality of; beef (100\%), fish (100\%), maize beans $(97.2 \%)$, rabbits $(100 \%)$ and honey $(84.6 \%)$ as illustrated in Table VI.

Table VI: On-farm benefits of promoted fodder technologies

\begin{tabular}{|c|c|c|c|c|c|c|c|c|}
\hline \multirow{3}{*}{ Farm Product } & \multicolumn{4}{|c|}{ Production } & \multicolumn{4}{|c|}{ Quality } \\
\hline & \multicolumn{2}{|c|}{ Increased } & \multicolumn{2}{|c|}{ No change } & \multicolumn{2}{|c|}{ Improved } & \multicolumn{2}{|c|}{ No change } \\
\hline & freq. & $\%$ & freq. & $\%$ & freq. & $\%$ & freq. & $\%$ \\
\hline Cow milk & 81 & 92.0 & 7 & 8.0 & 79 & 91.9 & 7 & 8.1 \\
\hline Goat milk & 44 & 91.7 & 4 & 8.3 & 44 & 91.7 & 4 & 8.3 \\
\hline Eggs & 11 & 84.6 & 2 & 15.4 & 12 & 92.3 & 1 & 7.7 \\
\hline Honey & 11 & 84.6 & 2 & 15.4 & 11 & 84.6 & 2 & 15.4 \\
\hline Fish & 4 & 100.0 & 0 & 0.0 & 4 & 100.0 & 0 & 0.0 \\
\hline Manure & 84 & 96.6 & 3 & 3.4 & 84 & 97.7 & 2 & 2.3 \\
\hline Maize & 77 & 97.5 & 2 & 2.5 & 76 & 97.4 & 2 & 2.6 \\
\hline Beans & 70 & 97.2 & 2 & 2.8 & 69 & 97.2 & 2 & 2.8 \\
\hline Beef & 9 & 100.0 & 0 & 0.0 & 9 & 100.0 & 0 & 0.0 \\
\hline Rabbit & 4 & 100.0 & 0 & 0.0 & 4 & 100.0 & 0 & 0.0 \\
\hline Bananas & 4 & 100.0 & 0 & 0.0 & 4 & 100.0 & 0 & 0.0 \\
\hline
\end{tabular}

\subsection{Adoption of agroforestry technologies}

The rate of adoption of fodder technologies was determined by the number of sampled farmers who allocated or planted the fodder trees on their farms and utilising them for various uses. From the study, $86 \%$ of the sampled 
farmers had adopted the technology. Further analysis to determine the number of adopters who had disseminated the technology to other farmers was undertaken. From the analysis, original project farmers had disseminated the technology to more farmers as compared to the adopters (Table VII).

Table VII: Number of farmers the technology was disseminated to by original famers and adopters

\begin{tabular}{llllll}
\hline Type of farmer & \multicolumn{1}{l}{ Number and percentage of farmers the technology was disseminated to } \\
\hline Range & $<100$ & $100 \_200$ & $200 \_300$ & $>300$ & Total \\
\hline \multirow{2}{*}{ Originals } & 46 & 2 & 2 & 2 & 52 \\
& $88.5 \%$ & $3.8 \%$ & $3.8 \%$ & $3.8 \%$ & $100.0 \%$ \\
\multirow{2}{*}{ Adopters } & 30 & 2 & 0 & 2 & 34 \\
& $88.2 \%$ & $5.9 \%$ & $0.0 \%$ & $5.9 \%$ & $100.0 \%$ \\
\multirow{2}{*}{ Total } & 76 & 4 & 2 & 4 & 86 \\
& $88.4 \%$ & $4.7 \%$ & $2.3 \%$ & $4.7 \%$ & $100.0 \%$ \\
\hline
\end{tabular}

\subsection{Determinants of agroforestry fodder technology adoption}

Various socio-economic factors influence technology adoption and uptake among farmers. Logistic regression was performed to ascertain the effects of gender, age, the level of education, the major source of income, primary source of expenditure, land ownership, land size, and land tenure, and farm gradient on the likelihood of adoption of fodder technology. The results from the regression analysis (Table VIII) indicate that the model was statistically significant, $\chi_{(3)}^{2}=16.661$, P-Value $<0.0005$. The model explained $31.0 \%$ (Nagelkerke $\mathrm{R}^{2}$ ) of the variance in the adoption of agroforestry technologies. Socio-economic factors; age, gender, years in education, and land size influenced adoption of agroforestry techniques. The likelihood to adopt was positively related to age. The number of years in education had a positive influence.

Table VIII: Logistic regression model for determinants of adoption of fodder technologies in Embu County

\begin{tabular}{|c|c|c|c|c|c|c|c|}
\hline \multirow{2}{*}{$\begin{array}{l}\text { Variables } \\
\text { Equation }\end{array}$} & \multirow[t]{2}{*}{ B } & \multirow[t]{2}{*}{ S.E. } & \multirow[t]{2}{*}{ Wald } & \multirow[t]{2}{*}{ Sig. } & \multirow[t]{2}{*}{$\operatorname{Exp}(B)$} & \multicolumn{2}{|c|}{$\begin{array}{l}\text { 95\% C.I.f for } \\
\text { EXP(B) }\end{array}$} \\
\hline & & & & & & Lower & Upper \\
\hline Gender & -1.053 & .373 & 7.983 & .005 & 7.3 & .168 & .724 \\
\hline Age & .027 & .017 & 7.440 & .008 & 1.0 & .993 & 1.062 \\
\hline Level of education & .171 & .276 & 5.383 & .036 & 0.4 & .491 & 1.448 \\
\hline Main source of income & .329 & .501 & 6.430 & .012 & 1.3 & .520 & 3.711 \\
\hline $\begin{array}{l}\text { Major source of } \\
\text { household expenditure }\end{array}$ & .124 & .163 & 3.581 & .146 & 1.1 & .823 & 1.557 \\
\hline Land ownership & 20.155 & 22636.24 & .000 & .999 & 566246583.3 & 0.000 & \\
\hline Land size & .430 & .201 & 4.556 & .033 & 1.5 & 1.036 & 2.280 \\
\hline Land tenure & -.051 & .496 & .011 & .918 & .9 & .359 & 2.512 \\
\hline Farm gradient & -.037 & .272 & 6.018 & .202 & .9 & .565 & 1.643 \\
\hline Constant & -20.116 & 22636.243 & .000 & .999 & .000 & & \\
\hline
\end{tabular}

Test statistic: $\chi^{2}{ }_{(3)}=16.661, \mathrm{P}-$ Value $<0.0005,31.0 \%\left(\right.$ Nagelkerke $\mathrm{R}^{2}$ )

\subsection{Discussion}

The findings indicate older farmers were more receptive to the fodder technology than young ones. This can be attributed to the fact that the calliandra project may have targeted the older farmers. However, age may constrain the adoption of fodder technologies since older farmers may not be enthusiastic to plant trees whose benefits are not immediate (Jera and Ajayi, 2008). Land size had a positive influence on adoption of agroforestry practices. Farmers adopting the fodder technologies had larger land sizes than non-adopters indicating direct relationship between land size and rate of adoption. This finding is in tandem with results of Ajayi et al., (2008) who found that land size has a positive influence on adoption of new technologies. Rana et al., 2000 and Fernandez-Cornejo et al., 2001 also reported that large farm sizes have a positive effect on adoption of agricultural technologies. Gender analysis indicates that male dominated female counterparts in the adoption of fodder technologies. The difference can be attributed to the fact that unlike men, women in majority of Kenyan communities have neither right to own agricultural production resources especially land nor power to make major decisions regarding agricultural productions and this renders women unable to acquire and use new agricultural technologies. The findings concur with that of Masuki et al. (2003). The low percentage of farmers with tertiary education can be attributed to the fact that farmers tend to engage in off-farm activities as education level increases (Akkaya et al., 2007). Findings of the study agreed with Boateng (2008), who found that high level of literacy would result in an increase in technical efficiency and decreased conservationism among farmers. The study revealed that Calliandra calothrysus has multiple benefits and has improved the livelihoods of the farmers. 


\subsection{CONCLUSION}

The findings of this study indicate that majority of the older farmers had adopted the growing of fodder trees as they owned the land. Farmers with larger farm sizes adopted the technology. The technology is providing multiple benefits to the farmers and the farming system. The study recommended that farmers should continue adopting fodder technologies for improved livelihoods.

\subsection{ACKNOWLEDGEMENT}

We are indebted to KEFRI for the financial support in carrying out this study. Enumerators who collected the data are also highly acknowledged. Finally, we wish to sincerely thank all the farmers who answered our questions during the survey.

\subsection{REFERENCES}

1. Ajayi, O. C., Akinnifesi, F. K., Sileshi, G., Chekeredza, S. and Mgomba, S. (2008).Payment for Environmental Services (PES): A Mechanism for Promoting Sustainable Agroforestry Land Use Practices among Smallholder Farmers in Southern Africa. Conference on International Research on Food Security, Natural Resources Management and Rural Development.ICRAF.Pp 3.

2. Akkaya, A, Gundogdu, S. T., Yaslioglu, K. S., Kirmikil, E. M. and Arici, I. (2007).Personal, Physical and Socioeconomic Factors Affecting Farmers' Adoption of Land Consolidation.Spanish Journal of Agricultural Research, 5(2), pp 204-213.

3. Barrios, E. (2007). Soil biota, ecosystem services and land productivity. Ecological. Economics, 64, pp 269285 .

4. Boateng, I. (2008). Impact of Agroforestry on the Livelihood of rural Farming Household. Unpublished B.sc Thesis of Department of Agroforestry.KwameNkrumah University of Science and Technology pp 2328.http://hdl.handle.net/123456789/591. Retrieved August 26, 2016.

5. Cook, B.G., Pengelly, B.C., Brown, S.D., Donnelly, J.L., Eagles, D.A., Franco, M.A., Hanson, J., Mullen, B.F., Partridge, I.J., Peters, M. and Schultze-Kraft, R. 2005. Tropical Forages an interactive selection tool., [CD-ROM], CSIRO, DPI\&F(Qld), CIAT and ILRI, Brisbane, Australia.

6. Fernandez-Cornejo, J., Daberkow, S. and McBride, W.D. (2001). Decomposing the Size Effect on the Adoption of Innovations: Agrobiotechnology and Precision Agriculture. Journal of Agrobiotechnology Management and Economics 4(2), pp 124-36.

7. Government of Kenya (2005). Economic Survey 2005. Government Printer, Nairobi.

8. Government of Kenya, 2010, Agricultural Sector Development Strategy 2010-2020

9. Gutteridge, R. C. and Shelton, H.M.J. (1994). Tree Legumes in Tropical Agriculture.CABI, Wallingford, UK. pp. 65-64.

10. Harvey, C.A., Komar, O., Chazdon, R., Ferguson, B.G., Finegan, B., Griffith, D.M., Martinez-Ramos, M., Morales, H., Nigh, R., Soto-Pinto, L., Van Breugel, M., Wishnie, M. (2008). Integrating agricultural landscapes with biodiversity conservation in the Mesoamerican hotspot. Conservation and Policy. 22, pp 815.

11. Hyde, W.F. and Köhlin, G. (2000). Social forestry reconsidered. Silva Fennica 34(3): pp 285-314.

12. Jera, R., \& Ajayi, O. C. (2008). Logistic modelling of smallholder livestock farmers' adoption of tree-based fodder technology in Zimbabwe. Agrekon, 47(3), 379-392.

13. Jerneck, A., \& Olsson, L. (2013). More than trees! Understanding the agroforestry adoption gap in subsistence agriculture: Insights from narrative walks in Kenya. Journal of Rural Studies, 32, 114-125.

14. Karanja, A. M. (2003). The dairy industry in Kenya: The post-liberalization agenda. Tegemeo Institute of Agricultural Policy and Development, Egerton University, Kenya, 60.

15. Masuki, F. G. K., Khamaldin, D. M., Siza, D. T., Filbert, B. R., Amon, Z. M. and Nuhu H. (2003). Smallholder System Innovations Programme, Soil-Water Management Research Group, Sokoine University of Agriculture, Morogoro, Tanzania.

16. Maundu, P. and Tengnas, T. (2005). Useful trees and shrubs for Kenya. Technical Handbook No. 35. Nairobi Kenya. Pp 140.

17. Minae, S. and Nyamai, D. (1988). Agroforestry Research Project Proposal for the Coffee-based Land Use System in the Bimodal Highlands, Central and Eastern Provinces, Kenya. (AFRENA Report 16). Nairobi: International Centre for Research in Agroforestry (ICRAF).

18. Mugambi, D. K. (2014, May). Estimation of milk production efficiency of dairy cow farms in Embu and Meru counties of Kenya. In Scientific Conference Proceedings.

19. Murithi, F. M. (1998). Economic evaluation of the role of livestock in mixed smallholder farms of the central highlands of Kenya. Economic evaluation of the role of livestock in mixed smallholder farms of the central highlands of Kenya.

20. Pretty, J., Noble, A., Bossio, D. (2006). Resource-conserving agriculture increases yields in developing 
countries. Environmental Science and Technology.40, pp 1114-1119.

21. Rana, R.B., Gauchan, D., Rijal, D.K., Khatiwada, S.P., Paudel, C.L., Chaudhary, P. and Tiwari, P.R. (2000). Socio-economic data collection and analysis: Nepal. In: Conserving Agricultural Biodiversity In Situ: A scientific basis for sustainable agriculture. IPGRI (International Plant Genetic Resources Institute), Rome, Italy. Jarvis, D., Sthapit, B. and Sears, L. (Eds), pp 54-56. 